\title{
Kinerja Produktivitas Usaha Perikanan dan Sistem Penyuluhan Perikanan di Kecamatan Sungai Menang, Provinsi Sumatera Selatan
}

\author{
[Performance Of Fisheries Business Productivity and Fisheries Extension \\ System in Sungai Menang District, South Sumatera Province] \\ Wahyu Firmansyah, Yenni Nuraini, Dwi Lambang Setyo Aji \\ Program Studi Penyuluhan Perikanan, Politeknik Ahli Usaha Perikanan \\ Jalan Cikaret No. 2 16232, Jawa Barat
}

\begin{abstract}
Abstrak
Kecamatan Sungai Menang merupakan salah satu wilayah yang memiliki potensi perikanan yang mumpuni baik dibidang usaha penangkapan, budidaya, serta pengolahan perikanan. Penelitian ini bertujuan untuk mengidentifikasi kinerja produktivitas perikanan dan sistem penyuluhan perikanan di Kecamatan Sungai Menang, Kabupaten Ogan Komering Ilir, Sumatera Selatan yang dilaksanakan pada 21 November 2020 sampai dengan 20 Januari 2021. Penelitian ini menggunakan analisis data kualitatif dan kuantitatif, sedangkan metode pengumpulan data menggunakan metode Participatory Rural Appraisal (PRA) melalui pengisian borang dan kuesioner. Sasaran pada penelitian ini berjumlah 23 orang yang terdiri dari 12 orang pembudidaya, 6 orang pengolah, dan 5 orang nelayan. Hasil penelitian menunjukkan jumlah produktivitas rata-rata dibidang usaha budidaya perikanan yang meliputi usaha pembesaran udang vannamei, udang windu dan ikan bandeng sebanyak $1.007 \mathrm{~kg} / \mathrm{siklus,} \mathrm{pada} \mathrm{bidang}$ perikanan tangkap dengan komoditas hasil tangkapan berupa rajungan dan udang jerbung sebanyak $264,2 \mathrm{~kg} / \mathrm{bulan}$, dan bidang usaha pengolahan perikanan berupa olahan terasi dan ikan asin sebanyak $260 \mathrm{~kg} /$ bulan. Berdasarkan hasil identifikasi kinerja produktivitas dan sistem penyuluhan perikanan, terdapat beberapa permasalahan pada aspek teknis maupun sosial yang diantaranya adalah keterbatasan modal dan infrastruktur, serta pengetahuan pelaku utama dalam penerapan SOP yang sesuai dengan bidang usahanya, sedangkan permasalahan pada sistem penyuluhan yaitu belum intensifnya kegiatan pendampingan terhadap kelompok/pelaku utama yang menyebabkan kegiatan penyuluhan belum berjalan dengan optimal.
\end{abstract}

Kata kunci : kinerja produktivitas; sistem penyuluhan perikanan; usaha perikanan

\begin{abstract}
Sungai Menang District is one of the areas that has good fishery potential in the field of catching, aquaculture, and fishery processing. This aim of this research was to identify fishery productivity and fishery extension systems in Sungai Menang District, Ogan Komering lir Regency, South Sumatra which was carried out from November 21, 2020 to January 20, 2021. This study used qualitative and quantitative data analysis, while the data collection method used the Participatory Rural method. Appraisal (PRA) through filling out forms and questionnaires. The target of this study found 23 people consisting of 12 cultivators, 6 processors, and 5 fishermen. The results showed that the average productivity in the field of aquaculture which includes as many as vannamei shrimp, tiger shrimp and shrimp as much as $1,007 \mathrm{~kg} / \mathrm{cycle}$, capture fisheries with catches in the form of crab and jerbung shrimp $264.2 \mathrm{~kg} / \mathrm{month}$, and the business sector fishery processing in the form of processed shrimp paste and fish as much as $260 \mathrm{~kg} / \mathrm{month}$. Based on the results of the performance and the extension system, there are several problems in the technical and social aspects, including limited capital and infrastructure, as well as the knowledge of the main actors in the application of SOPs in accordance with their business, while the problem with the extension system is that there is not yet intensive assistance to groups/main actors involved. This causes counseling activities to not run optimally.
\end{abstract}


Penulis Korespondensi

Wahyu Firmansyah | firmansyahw825@gmail.com

\section{PENDAHULUAN}

Kecamatan Sungai Menang merupakan salah satu wilayah yang memiliki potensi perikanan yang cukup baik. Produktivitas perikanan budidaya dan penangkapan ikan di Kecamatan Sungai Menang pada tahun 2017 mencapai 24.759 ton (BPS, 2020). Wilayah Kecamatan Sungai Menang berada di bagian tenggara Kabupaten Ogan Komering Ilir, Provinsi Sumatera Selatan tepatnya terletak diantara $105^{\circ} 15^{\prime}$ dan 10590' Bujur Timur dan $3^{\circ} 35^{\prime}$ sampai $4^{\circ} 10^{\prime}$ Lintang Selatan, dengan luas mencapai $2.768,17 \mathrm{~km}^{2}$.

Undang-undang Nomor 16 Tahun 2006 tentang Sistem Penyuluhan Pertanian, Perikanan dan Kehutanan (SP3K) menjelaskan bahwa penyuluhan memegang peranan yang cukup strategis dalam pembangunan di sektor perikanan. Kegiatan penyuluhan juga mampu mendorong terwujudnya nelayan dan pembudidaya ikan yang lebih baik, menuju kehidupan yang lebih layak, usaha yang lebih menguntungkan, dan hidup lebih sejahtera (Hanan et al. 2012).

Identifkasi potensi wilayah perikanan pada suatu wilayah merupakan salah satu upaya yang dapat dilakukan untuk mendorong pertumbuhan dan perkembangan berbagai bidang terutama di sektor kelautan dan perikanan sehingga berdampak pada terciptanya lapangan pekerjaan dan kesejahteraan masyarakat (Windi et al. 2021), dengan demikian melalui identifikasi potensi wilayah perikanan yang meliputi kondisi sumber daya alam, sumber daya manusia, dan sumber daya penunjang dapat dijadikan sebagai acuan untuk mendorong peningkatan produtivitas usaha perikanan berdasarkan kebutuhan dan potensi yang dimiliki.

Identifikasi potensi perikanan dan sistem penyuluhan perikanan perlu dilakukan untuk mengetahui potensi serta permasalahan yang terdapat pada kegiatan usaha perikanan dibidang budidaya, penangkapan, dan pengolahan perikanan sehingga kinerja produktivitas usaha perikanan dapat ditingkatkan melalui penyelesaian masalah yang terdapat di wilayah tersebut salah satunya melalui kegiatan penyuluhan berupa penerapan suatu inovasi untuk meningkatkan pengetahuan, sikap dan keterampilan pelaku utama sesuai dengan bidang usahanya masing-masing. 
Penelitian ini bertujuan untuk mengidentifikasi potensi perikanan, kinerja produktivitas usaha perikanan, serta sistem penyuluhan perikanan di Kecamatan Sungai Menang. Hasil identifikasi potensi wilayah perikanan dapat dijadikan sebagai acuan untuk menentukan rencana kegiatan penyuluhan berdasarkan potensi, permasalahan, dan kebutuhan yang dihadapi oleh pelaku utama/usaha di Kecamatan Sungai Menang.

\section{BAHAN DAN METODE}

Penelitian ini dilaksanakan pada tanggal 21 November 2020-20 Januari 2021 yang berlokasi di Kecamatan Sungai Menang, Kabupaten Ogan Komering Ilir, Provinsi Sumatera Selatan. Metode yang digunakan pada kegiatan penelitian ini adalah metode Participatory Rural Appraisal (PRA) atau Pemahaman Partisipatif Kondisi Pedesaan (PRA) yaitu pendekatan dengan metode yang memungkinkan masyarakat secara bersama-sama menganalisis masalah kehidupan dalam rangka merumuskan perencanaan dan kebijakan secara nyata (Supriatna 2014).

Jenis data yang digunakan dalam penelitian ini terdiri data primer dan data sekunder. Data primer merupakan sumber data penelitian yang langsung memberikan data kepada pengumpul data, sedangkan data sekunder merupakan sumber data penelitian yang tidak langsung memberikan data kepada pengumpul data, misalnya melalui orang lain atau dokumen (Batubara 2013).

Data primer pada kegiatan penelitian ini diperoleh melalui teknik wawancara, observasi dan dokumentasi di lapangan dengan kelompok perikanan, pelaku utama dan pelaku usaha dibidang budidaya, penangkapan, pengolahan serta penyuluh perikanan di Kecamatan Sungai Menang. Data sekunder berupa dokumen, baik yang belum atau sudah mengalami modifikasi serta pengolahan lebih lanjut.

Data sekunder pada kegiatan penelitian ini diperoleh dari Badan Pusat Statistik Kabupaten Ogan Komering Ilir, Dinas Perikanan Kabupaten Ogan Komering Ilir, Pemerintah Kecamatan Sungai Menang, Pemerintah Desa/ Kelurahan yang dijadikan sampel penelitian, studi literatur, dan internet. Populasi pada kegiatan penelitian ini merupakan pelaku utama pada bidang usaha perikanan budidaya, perikanan tangkap dan pengolahan hasil perikanan.

Teknik pengambilan sampel yang digunakan adalah teknik Snowball Sampling. Metode pengambilan sampel seperti ini khusus digunakan untuk datadata yang bersifat komunitas dari subjektif responden, atau dengan kata lain objek sampel yang kita inginkan 
sangat langka dan bersifat mengelompok pada suatu himpunan (Nurdiani 2014).

Jumlah Desa/Kelurahan yang dijadikan sampel pada penelitian ini adalah sebanyak 4 desa, yaitu Desa Bumi Pratama Mandira, Desa Bumi Asri Mandira, Desa Sungai Sibur, dan Desa Pinang Indah. Jumlah responden yang dijadikan sampel kegiatan penelitian ini terdiri dari 15 kelompok perikanan dan 23 orang pelaku utama perikanan yang meliputi 12 orang pembudidaya, 6 orang nelayan ,dan 5 orang pengolah.

Metode analisis data dilakukan dengan menggunakan metode kualitatif dan kuantitatif. Analisis kualitatif dilakukan dengan cara mendeskripsikan data yang berkaitan dengan potensi sumber daya alam, sumber daya manusia, kondisi umum usaha perikanan dan kondisi sumber daya penunjang. Data tersebut yang diperoleh melalui kegiatan wawancara maupun pengamatan secara langsung terhadap responden serta kondisi usaha perikanan yang terdapat di lapangan, sedangkan analisis kuantitatif dilakukan dengan melakukan kategorisasi terhadap data yang berbentuk angka seperti kinerja produksi usaha perikanan dan analisis usaha pada bidang budidaya perikanan, perikanan tangkap, dan pengolahan perikanan.

Alat pengumpulan data yang digunakan pada penelitian adalah borang dan kuesioner yang diberikan kepada responden penelitian terkait kegiatan usaha perikanan serta sistem penyuluhan perikanan di Kecamatan Sungai Menang, selanjutnya data yang telah diperoleh dilakukan proses pengolahan data yang meliputi beberapa tahapan diantaranya editing, coding, dan tabulasi data sehingga informasi pada data tersebut dapat diterima oleh pembaca.

\section{Identifikasi Potensi Perikanan}

Identifikasi potensi suatu wilayah merupakan salah satu kegiatan untuk menggali data dan informasi yang dilakukan secara partisipatif. Sektor kelautan dan perikanan merupakan salah satu sektor paling banyak melibatkan masyarakat pada setiap kegiatannya sehingga menjadi salah satu sumber pertumbuhan ekonomi baru dalam rangka meningkatkan pendapatan dan kesejahteraan masyarakat (Nurpajri, Wiryati, dan Sunaryo 2019).

Potensi sumber daya perikanan yang terdapat di Indonesia memiliki keanekaragaman hayati perairan yang sangat potensial, dalam melakukan identifikasi potensi perikanan di suatu wilayah harus mencakup seluruh kekayaan perikanan yang dapat dimanfaatkan untuk memenuhi kebutuhan hidup manusia baik dari segi kuantitas maupun kualitas (Nuitja 2010).

Identifikasi potensi wilayah perikanan dapat dilakukan melalui peng- 
amatan terhadap kondisi sumber daya alam, kondisi sumber daya manusia, kondisi sumber daya penunjang, serta kondisi umum usaha perikanan yang terdapat diwilayah tersebut sehingga dari hasil identifikasi tersebut dapat diperoleh alternatif pemecahan masalah berdasarkan kebutuhan dan potensi di wilayah tersebut.

\section{Metode PRA (Participatory Rural Appraisal)}

Metode Participatory Rural Appraisal (PRA) atau Pemahaman Partisipatif Kondisi Pedesaan (PRA) adalah pendekatan dan metode yang memungkinkan masyarakat dapat terlibat secara aktif untuk menganalisis masalah dalam rangka merumuskan perencanaan dan kebijakan secara nyata. Penerapan pendekatan dan teknik PRA dapat memberi peluang yang lebih besar dan lebih terarah untuk melibatkan masyarakat yang memungkinkan masyarakat desa untuk saling berbagi, meningkatkan, dan menganalisis pengetahuan mereka tentang kondisi dan kehidupan desa, serta membuat rencana dan tindakan secara partisipatif (Supriatna 2014).

\section{Prinsip Dasar PRA}

Menurut Supriatna (2014) prinsip dasar yang harus dipenuhi dalam metode PRA antara lain adalah saling belajar dan berbagi pengalaman, keterlibatan anggota kelompok, orang luar sebagai fasilitator, penerapan konsep triangulasi multidisipliner tim PRA, variasi teknik dan keragaman narasumber, serta orientasi praktis dan keberlanjutan program. Pendekatan PRA ini bertujuan memberikan dukungan yang efektif dalam proses perencanaan dan pelaksanaan pembangunan serta pemberdayaan masyarakat secara berkelanjutan dengan berwawasan lingkungan serta berbasis konteks lokal. Metode PRA dapat memberikan pemahaman kepada para aparatur pemerintahan desa dalam melakukan proses identifikasi potensi dan permasalahan di desanya.

\section{Sistem Usaha dan Bisnis Perikanan}

Sistem usaha perikanan merupakan seperangkat unsur yang secara teratur saling berkaitan sehingga membentuk suatu totalitas. Sistem usaha perikanan terdiri dari berbagai sub sistem yang tergabung dalam rangkaian interaksi secara reguler dan terorganisir sebagai suatu totalitas. Subsistem usaha perikanan terdiri dari pasokan input, proses produksi, pasca panen, pemasaran dan layanan pendukung (Firdaus 2008).

\section{Analisis Usaha}

R/C Ratio

$\mathrm{R} / \mathrm{C}$ ratio adalah salah satu analisis usaha untuk mengukur kelayakan suatu 
usaha yang menekankan pada penerimaan dan beberapa jenis pengeluaran (Wijayanto dan Kurohman 2018). Perhitungan $\mathrm{R} / \mathrm{C}$ ratio menggunakan rumus perhitungan sebagai berikut yaitu:

$$
\text { RC Ratio }=\frac{\text { Penerimaan }}{\text { Pengeluaran }}
$$

\section{Payback Period (PP)}

Payback period merupakan periode yang diperlukan untuk menutup kembali pengeluaran investasi pada suatu usaha (Judhaswati dan Damayanti 2018). Payback period (PP) adalah analisis untuk mengetahui rentang waktu yang diperlukan bagi aliran tunai yang dihasilkan oleh suatu kegiatan investasi untuk menutup semua biaya/modal awalnya (Setiawan et al. 2018). Pehitungan nilai Payback Period menggunakan rumus perhitungan sebagai berikut:

$$
\mathrm{PP}=\frac{\text { Investasi }}{\text { Kas Bersih per Tahun }} \times 1 \text { tahun }
$$

\section{Return Of Investement (ROI)}

Return of Investment (ROI) merupakan parameter untuk mengetahui tingkat pengembalian investasi dari penerimaan (benefit) yang diterima pemilik modal (Fauzi et al. 2011). Kegiatan usaha perikanan layak dikembangkan bila mempunyai nilai ROl>1 (satu). Perhitungan nilai $\mathrm{ROI}$ menggunakan rumus dibawah ini:

$$
\text { ROI }=\frac{\text { Laba Usaha }}{\text { Biaya Produksi }}
$$

\section{HASIL DAN PEMBAHASAN}

Hasil

Kondisi Umum Kecamatan Sungai Menang

Kecamatan Sungai Menang merupakan salah satu wilayah yang berada Kabupaten Ogan Komering llir dengan jarak ke lbu Kota Kabupaten \pm 175 km Kecamatan ini terletak di sebelah tenggara Ibu Kota Kabupaten Ogan Komering llir (Kayuagung) dengan ketinggian \pm 8 meter diatas permukaan laut, dengan luas wilayah 2.255,6 km², sebagian wilayah Kecamatan Sungai Menang merupakan wilayah perairan dan berbatasan dengan laut lepas. Kecamatan Sungai Menang terdiri atas 18 desa definitif dengan ibukota kecamatannya adalah Desa Sungai Menang (BPS, 2020). Peta wilayah Kecamatan Sungai Menang dapat dilihat pada Gambar 1. 
Kondisi Umum Sumber Daya Alam

Kecamatan Sungai Menang memiIki 18 desa yang sebagian besar wilayahnya didominasi oleh perairan, yang terdiri dari sungai, rawa, dan juga banyak ditumbuhi pohon mangrove. Komoditas ikan yang hidup di wilayah ini cukup beragam seperti ikan nila, kakap, baung, ikan patin, udang dan berbagai jenis ikan air payau lainnya (BPS, 2020). Kegiatan usaha disektor kelautan dan perikanan banyak dilakukan oleh masyarakat terutama yang berada di wilayah pesisir Kecamatan Sungai Menang melipui usaha dibidang budidaya perikanan, penangkapan ikan dan pengolahan hasil perikanan.

Kegiatan budidaya perikanan yang banyak dilakukan di Kecamatan Sungai Menang antara lain budidaya udang vannamei dengan sistem tradsional plus, semi intensif dan intensif, serta budidaya ikan bandeng dan udang windu (sistem polikultur), pada bidang usaha penang- kapan ikan, komoditas hasil tangkapan utama nelayan seperti rajungan, udang jerbung, ikan kakap, dan jenis ikan lainnya yang bergantung pada keadaan cuaca. Bidang usaha pengolahan hasil perikanan juga merupakan salah satu jenis usaha yang cukup banyak dilakukan meskipun pelaku utamannya tidak sebanyak pada bidang budidaya maupun penangkapan. Jenis olahan hasil perikanan seperti yaitu ikan asin dan terasi udang yang masih dilakukan dengan sistem tradisional.

Kondisi Umum Sumber Daya Manusia Jumlah penduduk di Kecamatan Sungai Menang adalah sebanyak 31.319 jiwa, yang terdiri dari 16.628 laki-laki dan 14.691 perempuan, dengan kepadatan penduduk mencapai $14 \mathrm{jiwa} / \mathrm{km}^{2}$. Jika dilihat dari angka tersebut, di kecamatan ini jumlah penduduk laki-laki lebih banyak dari perempuan dengan sex ratio 113 , artinya dari 100 orang perempuan

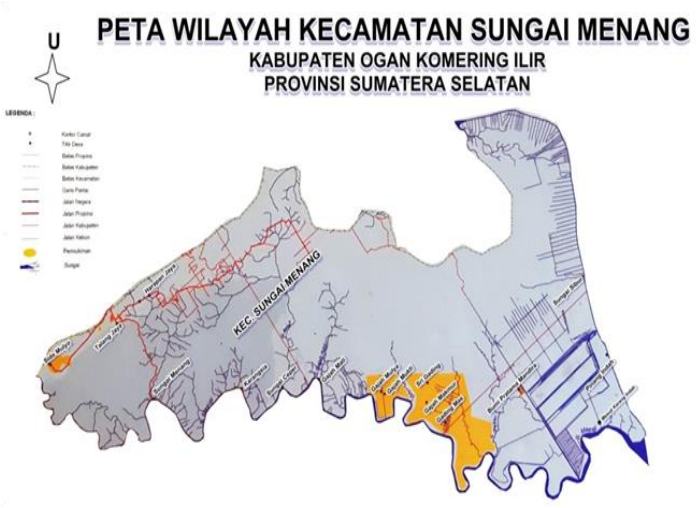

Gambar 1 Peta wilayah Kecamatan Sungai Menang 
terdapat lebih kurang 113 orang laki-laki (BPS, 2020)

\section{Kondisi Umum Usaha Perikanan}

Peneltian ini mengambil sampel pada beberapa desa dengan mempertimbangkan potensi perikanan. Desa yang dijadikan sampel yaitu Desa Bumi Pratama Mandira, Desa Bumi Asri Mandira, Desa Sungai Pinang Indah, dan Desa Sungai Sibur. Jumlah Rumah Tangga Perikanan (RTP) di desa sampel terdiri dari beberapa komoditas usaha yaitu budidaya, penangkapan, pengolahan. Jumlah RTP yang terbanyak adalah di Desa Bumi Pratama Mandira dengan jumlah 2.966, Desa Sungai Pinang Indah dengan jumlah RTP sebanyak 2.644, Desa Sungai Sibur sebanyak 1.328 dan Desa Bumi Asri
Mandira sebanyak 324 RTP, dengan total keseluruhan Rumah Tangga Perikanan (RTP) dari desa sampel di Kecamatan Sungai Menang adalah sebanyak 7.262 RTP.

\section{Kondisi Sumber Daya Penunjang}

Lembaga penunjang memiliki peranan yang sangat besar dalam pengembangan agribisnis. Subsistem penunjang terdiri atas semua pemain utama yang menyediakan jasa, meskipun bersifat pilihan, namun sangat penting dalam menunjang keberhasilan pada sistem usaha. Jasa-jasa disediakan oleh pemerintah, asosiasi, kredit, dan pembiayaan, lembaga penelitian, asosiasi, kelompok tani, dan koperasi (Ratna W et al. 2013).

Sumber daya penunjang kegiatan usaha perikanan di Kecamatan Sungai

Tabel 1 Karakteristik responden desa/kelurahan sampel

\begin{tabular}{|c|c|c|c|}
\hline Kriteria & Kategori & $\begin{array}{l}\text { Jumlah } \\
\text { responden } \\
\text { (orang) }\end{array}$ & $\begin{array}{c}\text { Persentase } \\
(\%)\end{array}$ \\
\hline \multirow[t]{3}{*}{ Umur } & Muda ( $\leq 35$ tahun) & 2 & 8,69 \\
\hline & Sedang (36-56 tahun) & 18 & 78,26 \\
\hline & Tua ( $\geq 57$ tahun) & 3 & 13,04 \\
\hline \multirow[t]{3}{*}{ Tingkat pendidikan } & Tinggi (D3-S3) & 0 & 0 \\
\hline & Sedang (SLTP-SLTA) & 14 & 60,8 \\
\hline & Rendah (Tidak sekolah-SD) & 9 & 39,13 \\
\hline \multirow[t]{3}{*}{ Tahun mulai usaha } & Lama $(\leq$ tahun 1990$)$ & 2 & 8,69 \\
\hline & Cukup Lama ( tahun 1991-2003) & 19 & 82,60 \\
\hline & Baru ( $\geq 2004)$ & 2 & 8,69 \\
\hline Jumlah & & 23 & 100 \\
\hline
\end{tabular}


Tabel 2 Perbandingan kinerja produktivtas dan analisis usaha budidaya perikanan

\begin{tabular}{llllllll}
\hline No & Nama RTP & FCR & SR (\%) & $\begin{array}{c}\text { Biomass } \\
(\mathbf{k g})\end{array}$ & $\mathbf{R} / \mathbf{C}$ & $\begin{array}{c}\text { ROI } \\
(\%)\end{array}$ & PP \\
\hline 1 & Aminurahman & 1,5 & 75 & 3,000 & 2.4 & 136 & 0.19 \\
2 & Julidam & 1,6 & 75 & 2.1 & 2,07 & 107 & 0.35 \\
3 & M. Catur & 1,7 & 70 & 1,050 & 2,2 & 122 & 0,38 \\
4 & Widarsah & 1,5 & 70 & 1.3 & 2.4 & 139 & 0.21 \\
5 & Peryanto & 1,4 & 85 & 1.5 & 2.9 & 186 & 0.3 \\
6 & Widodo & 1,3 & 93 & 687 & 2.8 & 126 & 0.29 \\
7 & Tarno & 1,1 & 87 & 500 & 2.8 & 180 & 0.14 \\
8 & Irwan & 1,2 & 90 & 380 & 2.6 & 159 & 0,20 \\
9 & Nurahman & 1,3 & 30 & 650 & 1.19 & 19 & 1.33 \\
10 & Suwadi & 1,3 & 35 & 750 & 1.2 & 19 & 0.94 \\
11 & Abdul Rahman & 1,4 & 30 & 800 & 1.25 & 25 & 0.77 \\
12 & Jamari & 1,4 & 28 & 600 & 1.18 & 18 & 1.4 \\
\hline Jumlah & $\mathbf{1 6 , 7}$ & $\mathbf{7 6 8}$ & $\mathbf{8 , 4 2 2}$ & $\mathbf{2 4 , 9 9}$ & $\mathbf{1 . 2 3 6}$ & $\mathbf{6 , 5}$ \\
\hline Rata-rata & $\mathbf{1 . 3 9}$ & $\mathbf{6 4}$ & $\mathbf{7 0 3 . 5}$ & $\mathbf{2 . 0 8}$ & $\mathbf{1 0 3}$ & $\mathbf{0 . 5 4}$ \\
\hline
\end{tabular}

Tabel 3 Perbandingan kinerja produktivitas dan analisis usaha perikanan tangkap

\begin{tabular}{llccccc}
\hline No. & Nama & $\begin{array}{c}\text { Frekuensi } \\
\text { Trip/Bulan }\end{array}$ & $\begin{array}{c}\text { Hasil } \\
\text { /Bulan } \\
\text { (Kg) }\end{array}$ & R/C & $\begin{array}{c}\text { ROI } \\
\mathbf{( \% )}\end{array}$ & PP \\
\hline 1 & Sukri & 25 & 300 & 1.45 & 45 & 1 \\
2 & Dedi Sandra & 26 & 312 & 1.44 & 44 & 1.09 \\
3 & Ical & 27 & 270 & 1,58 & 58 & 0,86 \\
4 & Ahmad & 29 & 377 & 1.68 & 68 & 0.58 \\
5 & PikalDarmi & 23 & 230 & 1.35 & 35 & 1.27 \\
6 & Ujang Ayat & 24 & 216 & 1.24 & 24 & 1.81 \\
\hline Jumlah & $\mathbf{1 5 4}$ & $\mathbf{1 7 0 5}$ & $\mathbf{8 , 7 4}$ & $\mathbf{2 7 4}$ & $\mathbf{6 . 6 1}$ \\
\hline Rata-rata & $\mathbf{2 5 . 7}$ & $\mathbf{2 8 4 . 2}$ & $\mathbf{1 , 4 5}$ & $\mathbf{4 5}$ & $\mathbf{1 . 1}$ \\
\hline
\end{tabular}

Menang terdiri dari Lembaga pemerintah dan non pemerintah. Lembaga pemerintah yaitu Dinas Perikanan Kabupaten
Ogan Komering llir, Pemerintah Kecamatan Sungai Menang, dan Pemerintah Desa, sedangkan lembaga non peme- 
rintah meliputi koperasi, Lembaga Swadaya Masyarakat (LSM), toko saprotan, serta perusahaan swasta yang menyediakan kebutuhan sarana dan prasana serta memfasilitasi pelaku utama/usaha dalam hal pemasaran.

\section{Kondisi Potensi dan Karakteristik} Responden

Responden pada penelitian ini merupakan pelaku utama perikanan, baik dari segmentasi budidaya, penangkapan dan pengolahan perikanan, karakteritk responden terdiri dari beberapa aspek yaitu umur, pendidikan dan lama usaha. Karakteristik responden di desa sampel Kecamatan Sungai Menang dapat dilihat pada Tabel 1.
Kinerja Produktivitas Usaha Perikanan

\section{Budidaya Perikanan}

Kegiatan usaha budidaya perikanan di Kecamatan Sungai Menang yang paling dominan yaitu pada segmentasi pembesaran ikan air payau, seperti udang vannamei, udang windu dan ikan bandeng sistem polikultur. Perbandingan kinerja produktivitas dan analisis usaha dibidang budidaya perikanan dapat dilihat pada Tabel 2.

\section{Perikanan Tangkap}

Bidang perikanan tangkap merupakan salah satu bidang usaha yang cukup banyak dilakukan oleh masyarakat khususnya pelaku utama/usaha di Kecamatan Sungai Menang, dimana komoditas hasil tangkapan utama para nelayan berupa rajungan dan udang jerbung. Perbandingan kinerja produktivitas dan

Tabel 4 Perbandingan kinerja produktivitas dan analisis usaha pengolahan perikanan

\begin{tabular}{ccccccc} 
J. $\begin{array}{c}\text { Nama } \\
\text { RTP }\end{array}$ & Jenis Olahan & $\begin{array}{c}\text { JumlahProduksi } \\
\mathbf{( k g ) / \text { Hari }}\end{array}$ & $\begin{array}{c}\text { FrekuensiProduksi/ } \\
\text { Minggu }\end{array}$ & R/C & $\begin{array}{c}\text { ROI } \\
(\%)\end{array}$ & PF \\
\hline Samsini & Terasi & 12 & 4 & 1.6 & 63 & 0.01 \\
Nayah & Terasi & 20 & 4 & 1.48 & 36 & 0.1 \\
Risam & Ikan Asin & 27 & 3 & 1.5 & 51 & 0.0 \\
Jarona & Ikan Asin & 24 & 3 & 1.5 & 48 & 0.0 \\
Edi & Ikan Asin & 15 & 3 & 1.4 & 40 & 0.0 \\
\hline Imlah & & $\mathbf{9 8}$ & $\mathbf{1 7}$ & $\mathbf{7 . 4 8}$ & $\mathbf{2 0 8}$ & $\mathbf{0 . 2}$ \\
\hline ata-rata & & $\mathbf{1 9 . 6}$ & $\mathbf{3 . 4}$ & $\mathbf{1 . 4 9}$ & $\mathbf{4 1 . 6}$ & $\mathbf{0 . 0}$ \\
\hline
\end{tabular}


analisis usaha bidang perikanan tangkap di Kecamatan Sungai Menang dapat dilihat pada Tabel 3.

\section{Pengolahan Perikanan}

Pengolahan hasil perikanan merupakan salah satu jenis usaha yang cukup banyak dilakukan terutama bagi masyarakat yang berada di wilayah pesisir, kegiatan usaha pengolahan yang paling banyak dilakukan di Kecamatan Sungai Menang yaitu olahan ikan asin dan terasi udang yang masih dilakukan secara tradisional. Kinerja produktivitas dan analisis usaha pengolahan hasil perikanan dapat dilihat pada Tabel 4.

\section{Sistem Penyuluhan Perikanan}

Kelembagaan Penyuluhan Perikanan

Kelembagaan penyuluhan perikanan di Kabupaten Ogan Komering Ilir terdiri dari Balai Riset Perikanan Perairan Umum dan Penyuluhan Perikanan (BRPPUPP) Palembang dan Dinas Perikanan Kabupaten Ogan Komering Ilir. Dinas Perikanan merupakan salah satu instansi yang menangani segala bentuk kegiatan perikanan terutama pada lingkup kecamatan yang terdapat di dalamnya, sedangkan Balai Riset Perikanan Perairan Umum dan Penyuluhan Perikanan (BRPPUPP) Palembang merupakan wadah yang menaungi penyuluh perikanan dan mendukung segala bentuk kegiatan yang berkaitan dengan kegiatan penyuluhan perikanan di beberapa wilayah salah satunya di Kecamatan Sungai Menang.

\section{Keragaan Penyuluh Perikanan}

Keragaan penyuluh perikanan di Kecamatan Sungai Menang adalah sebanyak 4 orang yang terdiri dari 2 orang penyuluh PNS dan 2 orang Penyuluh Perikanan Bantu (PPB). Ketenagaan Penyuluh Perikanan Kecamatan Sungai Menang berada dalam Satuan Administrasi Pangkal (Satminkal) Balai Riset Perikanan Perairan Umum dan Penyuluhan Perikanan (BRPPUPP) Palembang. Keragaan penyuluh perikanan di Kecamatan Sungai Menang dapat dilihat pada Tabel 5.

\section{Keragaan Kelompok Perikanan}

Kelompok perikanan di Kecamatan Sungai Menang, terdiri dari bidang usaha penangkapan, budidaya, dan juga pengolahan. Jumlah desa/kelurahan yang menjadi wilayah binaan penyuluh adalah sebanyak 4 desa, jumlah kelompok di Kecamatan Sungai Menang berdasarkan bidang usahanya dapat dilihat pada Tabel 6. 
Tabel 5 Keragaan penyuluh perikanan Kecamatan Sungai Menang

\begin{tabular}{llcl} 
No & \multicolumn{1}{c}{ Nama } & $\begin{array}{c}\text { Jenis } \\
\text { Penyuluh }\end{array}$ & $\begin{array}{c}\text { Bidang } \\
\text { Keahlian }\end{array}$ \\
\hline 1 & Dwi Lambang Setyo Aji S.P & PNS & Perikanan \\
2 & Akhmad Septy R. S.Pi & PNS & Perikanan \\
3 & Fauzan Ansori S.Pi & PPB & Perikanan \\
4 & Ditra Fajri, A.Md & PPB & Perikanan \\
\hline
\end{tabular}

Tabel 6 Jumlah kelompok berdasarkan bidang usaha

\begin{tabular}{llcccc}
\hline \multirow{2}{*}{ No. } & \multirow{2}{*}{ Desa/Kelurahan } & \multicolumn{3}{c}{ Bidang Usaha } & \multirow{2}{*}{ Jumlah } \\
\cline { 3 - 5 } & & Pokdakan & Poklahsar & KUB & \\
\hline 1 & BumiPratama Mandira & 24 & & & 24 \\
2 & Bumi Asri Mandira & 27 & & & 27 \\
3 & Sungai Sibur & & & 10 & 10 \\
4 & Pinang Indah & 10 & 4 & 8 & 22 \\
\hline & Jumlah & $\mathbf{6 1}$ & $\mathbf{4}$ & $\mathbf{1 8}$ & $\mathbf{8 3}$ \\
\hline
\end{tabular}

\section{Pembahasan}

Kondisi dan Karakteristik Responden

Berdasarkan data yang terdapat pada Tabel 1, dari total 23 responden, persentase usia responden dominan berada pada kategori sedang yaitu berkisar 36-56 tahun, yang dapat dikatakan bahwa umur sasaran ini masuk pada kategori umur produktif. Penduduk usia produktif adalah penduduk yang masuk dalam rentang usia antara 15- 64 tahun (Sukmaningrum dan Imron 2017). Burhansyah (2014) menyatakan bahwa pelaku utama berada pada usia produktif sehingga kegiatan inovasi yang dilakukan dapat mengandalkan para pelaku utama perikanan untuk mengembangkan inovasi yang diberikan dan juga mampu untuk menerapkannya. Tingkat pendidikan responden yang paling dominan adalah kategori sedang, terbatasnya jumlah sarana pendidikan serta akses transportasi yang belum memadai di beberapa desa yang menyebabkan banyak dari masyarakat yang memilih untuk bekerja dibandingkan untuk melanjutkan pendidikan.

Kriteria tahun mulai usaha, sebagian besar responden termasuk ke dalam kategori cukup lama dalam melakukan usaha di bidang perikanan baik sebagai pembudidaya, pengolah, maupun nelayan. Lama seseorang dalam bekerja dapat dikaitkan dengan 
pengalaman yang didapatkan di tempat kerja. Semakin lama seorang pekerja semakin banyak pengalaman dan semakin tinggi pengetahuannya dan keterampilannya (Harahap 2019).

\section{Kinerja Produktivitas Usaha}

\section{Budidaya Perikanan}

Kegiatan usaha budidaya udang vannamei, serta polikutur (udang windu dan ikan bandeng). Berdasarkan Tabel 2, FCR rata-rata adalah sebesar 1,39 , sedangkan rata-rata $\mathrm{SR}$ adalah $64 \%$, dengan nilai produksi rata-rata $703,5 \mathrm{~kg} / \mathrm{siklus}$. Perbedaan yang paling terlihat pada sistem budidaya diatas adalah penerapan teknologi, jumlah tebar, serta ketersediaan sarana dan prasarana produksi yang digunakan, tingkat penerapan teknologi dan produktivitas pada kegiatan budidaya udang perikanan masih tergolong relatif rendah, kurangnya pengetahuan mengenai manajemen pakan, tingginya harga pakan, kurangnya penerapan biosekuriti dan pengelolaan kualitas air, kondisi iklim dan cuaca, serta penerapan SOP yang dilakukan selama kegiatan produksi pada kegiatan budidaya perikanan yang belum optimal sehingga berdampak pada tingginya resiko terserang penyakit dan tingginya angka kematian (mortalitas).

Kegiatan pembesaran udang windu dan ikan bandeng yang banyak dilakukan oleh pembudidaya melalui sistem polikuttur. Polikultur adalah alternatif mengatasi permasalahan air yang disebabkan karena penurunan produksi ikan di kolam yang terdiri terdiri dari dua sampai tiga komoditas yaitu udang windu (Penaeus monodon), ikan bandeng (Chanos-chanos) dan rumput laut (Gracillaria sp) (Murachman, Nuhfil Hanani 2010).

\section{Perikanan Tangkap}

Udang jerbung dan rajungan adalah dua jenis ikan yang menjadi prioritas tangkapan nelayan pada desa/ kelurahan di Kecamatan Sungai Menang. Berdasarkan data produktivitas hasil tangkapan pada Tabel 3, jumlah rata-rata hasil tangkapan perharinya $11 \mathrm{~kg}$, dalam setiap bulannya nelayan rata-rata melakukan penangkapan sebanyak 25,7 kali perbulan, dengan hasil tangkapan rata-rata perbulannya adalah $284,2 \mathrm{~kg}$. Jumlah produktivitas hasil tangkapan nelayan rajungan dan udang jerbung sangat dipengaruhi dengan faktor alam dan ekonomi, faktor alam yaitu seperti kondisi iklim dan cuaca yang tidak menentu, sedangkan faktor ekonomi yaitu semakin tingginya biaya melaut, hasil tangkapan yang cenderung menurun dan fluktuasi harga ikan (Nurhayati 2013) 


\section{Pengolahan Perikanan}

Berdasarkan Tabel 4, dari total 5 orang responden yang terdiri dari pengolah terasi dan ikan asin, dengan jumlah produksi rata-rata dalam satu kali produksi adalah 19,6 kg. Frekuensi ratarata produksi dalam satu minggu adalah 3-4 kali produksi/minggu. Produktivitas dan frekuensi produksi yang dilakukan sangat bergantung pada ketersediaan bahan baku serta keadaan cuaca. Keadaan ini sangat mempengaruhi kegiatan usaha pengolahan terasi dan ikan asin yang masih menggunakan sistem tradisional. Kondisi pengolah ikan tradisional secara umum masih belum mampu menangani bahan baku secara baik, belum menerapkan proses produksi secara saniter dan higienis (Indrastuti, Wulandari, dan Palupi 2019).

\section{Kondisi Sistem Penyuluhan Perikanan}

Kelembagaan penyuluhan perikanan di Kecamatan Sungai Menang terdiri Balai Riset Perikanan Perairan Umum dan Penyuluhan Perikanan (BRPPUPP) Palembang dan Dinas Perikanan Kabupaten Ogan Komering Ilir. Jumlah penyuluh perikanan sebanyak 2 orang penyuluh PNS dan 2 orang Penyuluh Perikanan Bantu (PPB).

Jumlah kelompok berdasarkan bidang usahanya serta merupakan kelompok yang menjadi binaan penyuluh perikanan Kecamatan Sungai Menang, adalah sebanyak 83 kelompok, yang terdiri dari 61 Kelompok Pembudidaya Ikan (POKDAKAN), 4 Kelompok Pengolah dan Pemasar (POKLAHSAR), dan 18 Kelompok Usaha Bersama (KUB.

Permasalahan pada kinerja kelompok perikanan di Kecamatan Sungai Menang diantaranya kurangnya pengetahuan pelaku utama mengenai tugas dan fungsi kelompok, rendahnya minat pelaku utama untuk berkelompok, tingkat partisipasi anggota kelompok masih rendah, serta belum intensifnya kegiatan penyuluhan dan pendampingan kelompok perikanan di Kecamatan Sungai Menang. Peran penyuluh adalah sebagai komunikator dan fasilitator secara parsial berpengaruh terhadap pengembangan kelompok (Marbun, Satmoko, dan Gayatri 2019).

\section{SIMPULAN DAN SARAN}

\section{Simpulan}

Kecamatan Sungai Menang memiliki potensi perikanan yang cukup besar baik dibidang budidaya, penangkapan dan pengolahan. Jumlah produktivitas rata-rata pada bidang budidaya perikanan yang meliputi usaha pembesaran udang vannamei, udang windu dan ikan bandeng sebanyak $1.007 \mathrm{~kg} / \mathrm{siklus}$, bidang perikanan tangkap dengan komoditas hasil tangkapan berupa rajungan dan udang jerbung sebanyak 264,2 kg/bulan, serta bidang usaha 
pengolahan perikanan berupa olahan terasi dan ikan asin sebanyak 260 $\mathrm{kg} / \mathrm{bulan}$.

Kinerja produktivitas usaha perikanan di Kecamatan Sungai Menang tergolong memiliki potensi yang cukup baik meskipun dari segi produktivtasnya belum optimal. Hal ini disebabkan oleh keterbatasan permodalan, sarana dan prasarana, serta kurangnya pengetahuan pelaku utama dalam penerapan SOP dan pemanfaatan teknologi berdasarkan bidang usahannya,

Sistem penyuluhan perikanan di Kecamatan Sungai Menang sudah berjalan meskipun pada pelaksanaannya belum optimal yang disebabkan oleh kurangnya pengetahuan pelaku utama mengenai tugas dan fungsi kelompok, rendahnya minat pelaku utama untuk berkelompok, tingkat partisipasi anggota kelompok masih rendah, serta belum intensifnya kegiatan penyuluhan dan pendampingan kelompok perikanan di Kecamatan Sungai Menang.

\section{PERSANTUNAN}

Ucapan terimakasih penulis sampaikan kepada Seluruh Civitas Akademika Politeknik Ahli Usaha Perikanan Program Studi Penyuluhan Perikanan, Dinas Perikanan Kabupatan Ogan Komering llir, Pemerintah Kecamatan Sungai Menang, Pemerintah Desa Bumi Pratama Mandira, Desa Sungai Sibur,
Desa Pinang Indah, dan Desa Bumi Asri Mandira, pelaku utama serta seluruh Penyuluh Perikanan di Kecamatan Sungai Menang yang telah memberikan dukungan, bimbingan, dan semangat dalam penelitian dan penulisan jurnal ini.

\section{DAFTAR PUSTAKA}

Badan Pusat Statistik Kabupaten Ogan Komering Ilir. 2020. Kecamatan Sungai Menang Dalam Angka 2020. Kayu Agung: CV. Sultan Bumi Raya.

Batubara, Helmina. 2013. "Penentuan Harga Pokok Produksi Berdasarkan Metode Full Costing Pada Pembuatan Etalase Kaca Dan Alumunium Di Ud. Istana Alumunium Manado." Jurnal EMBA 1(3):217-24.

Burhansyah, Rusli. 2014. "Faktor-faktor yang mempengaruhi adopsi inovasi pertanian pada gapoktan puap dan non puap di Kalimantan Barat (Studi Kasus: Kabupaten Pontianak dan Landak)." Informatika Pertanian 23(1):65-74.

Fauzi, Syafril, Budhi Hascaryo Iskandar, Bambang Murdiyanto, dan Eko Sri Wiyono. 2017. "Kelayakan Finansial Usaha Perikanan Tangkap di Selat Bali." Jurnal Teknologi Perikanan dan Kelautan 2(1):37-46. 
Firdaus, Muhammad. 2008. Manajemen Agribisnis. Jakarta: Bumi Aksara.

Hanan, Abdul, Walson H. Sinaga, dan Nayu Nurmalia. 2012. "Hubungan Karakteristik Pelaku Utama Perikanan dengan Kebutuhan Materi Penyuluhan Perikanan (Studi Kasus di Kabupaten Purbalingga Provinsi Jawa Tengah." Jurnal Penyuluhan Perikanan dan Kelautan 6(1):1-11.

Harahap, Susi Susilawati. 2019. "Hubungan Usia, Tingkat Pendidikan, Kemampuan Bekerja dan Masa Bekerja Terhadap Kinerja Pegawai dengan Menggunakan Metode Pearson Correlation." Teknovasi 6(2):1226.

Indrastuti, Nindya Atika, Nur Wulandari, dan Nurheni Sri Palupi. 2019. "Profil Pengolahan Ikan Asin di Wilayah Pengolahan Hasil Perikanan Tradisional (PHPT) Muara Angke." Jurnal Pengolahan Hasil Perikanan Indonesia 22(2):218-28.

Judhaswati, Ratna Dewi, dan Herna Octivia Damayanti. 2018. "Kelayakan Usaha Pengolahan Limbah Kulit Udang dan Rajungan (Studi di Kabupaten Situbondo dan Banyuwangi Provinsi Jawa Timur)." CAKRAWALA 12(2):11836.
Marbun, Desy Natasha V.D., Sriroso Satmoko, dan Siwi Gayatri. 2019. "Peran Penyuluh Pertanian dalam Pengembangan Kelompok Tani Tanaman Hortikultura di Kecamatan Siborongborong, Kabupaten Tapanuli." Jurnal Ekonomi Pertanian dan Agribisnis 3(3):537-46.

Murachman, Nuhfil Hanani, Soemarno dan Sahri Muhammad. 2010. "Model Polikultur Udang Windu (Penaeus monodon Fab), Ikan Bandeng (Chanos-chanos Forskal) dan Rumput Laut (Gracillaria sp.) Secara Tradisional." Jurnal Pembangunan dan Alam Lestari 1(1):1-10.

Nuitja, I. Njoman Sumerta. 2010. Manajemen Sumber Daya Perikanan. Bogor (ID): IPB Press. Nurdiani, Nina. 2014. “Teknik Sampling Snowball dalam Penelitian Lapangan." ComTech: Computer, Mathematics and Engineering Applications 5(2):1110.

Nurhayati, A. 2013. "Analisis Potensi Lestari Perikanan Tangkap di Kawasan Pangandaran." Jurnal Akuatika Indonesia 4(2):244074. 
Nurpajri, Yeni, Ganjar Wiryati, dan Ade Sunaryo. 2019. "Identifikasi

Potensi Perikanan di Kecamatan

Parigi Kabupaten Pangandaran

Provinsi Jawa Barat." Jurnal

Penyuluhan Perikanan dan Kelautan 13(1):29-41.

Ratna W, Asmarataka, Harianto,

Suharno, Andriyono K., Lukman

Adhi, M. Baga, dan Maryono. 2013.

"Kajian Subsistem Penunjang

Agribisnis Karet di Jambi." Hal.

177-94 in Prosiding Seminar

Penelitian Unggulan Departemen

Agribisnis, diedit oleh D.

Rachmina, R. Nurmalina, R.

Winandi, N. Kusnadi, Burhanuddin,

dan A. Fariyanti. Bogor:

Departemen Agribisnis Fakultas

Ekonomi dan Manajemen Institut

Pertanian Bogor.

Setiawan, Wahyu, Atikah Nurhayati, Titin

Herawati, dan Asep Agus Handaka. 2018. "Kelayakan Usaha Penangkapan Ikan Menggunakan Jaring Insang (Gill Net) di Waduk Jatigede Kabupaten Sumedang." PAPALELE: Jurnal Penelitian Sosial Ekonomi Perikanan dan Kelautan 2(1):8-14.
Sukmaningrum, Adisti, dan Ali Imron. 2017. "Memanfaatkan Usia Produktif dengan Usaha Kreatif Industri Pembuatan Kaos pada Remaja di Gresik." Paradigma 5(3). Supriatna, Asep. 2014. "Relevansi Metode Participatory Rural Appraisal Dalam Mendukung Implementasi Undang-Undang Pemerintahan Desa." Jurnal Lingkar Widyaiswara 1(1):39-45.

Undang-undang Nomor 16 Tahun. 2006. tentang Sistem Penyuluhan Pertanian, Perikanan, dan Kehutanan.

Wijayanto, Dian, dan Faik Kurohman. 2018. "Karakteristik Usaha Perikanan Tangkap Mini Purse Seine yang Berpangkalan di PPI Karanganyar Kabupaten

Rembang." Jurnal Perikanan Tangkap 2(1):1-5.

Windi, Uray, Nur Istiqamah, dan Muslimah. 2021. "Identifikasi Potensi Perikanan Air Tawar Di Desa Perigi Landu Kecamatan Sejangkung Kabupaten Sambas." NEKTON: Jurnal Perikanan dan IImu Kelautan 1(1):36-43. 